\title{
EUROPEAN CONGRESS OF CARDIOLOGY
}

The first European Congress of Cardiology was held on September 9-12, 1952, in the

University of London. It was organized by the British Cardiac Society on behalf of the European Society of Cardiology.

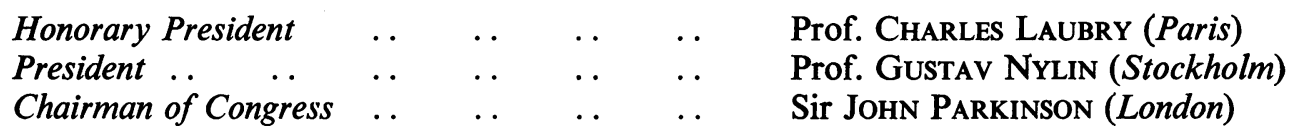

\section{ORgANizing COMMitTeE OF THE CONGRESS}

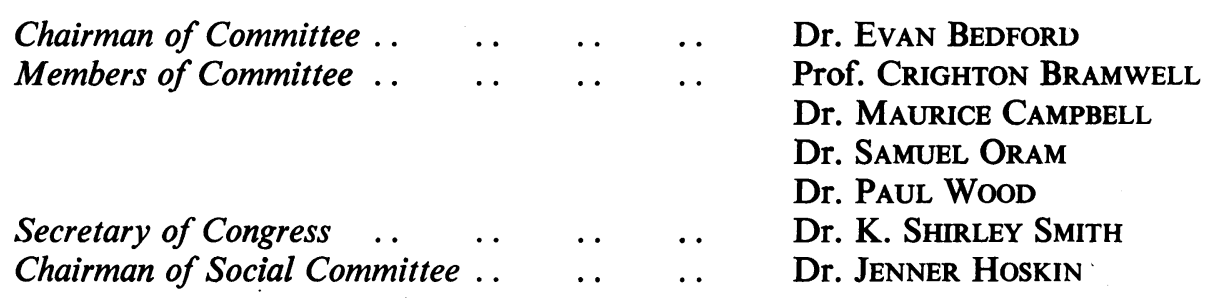

OfFicers of THE EuROPEAN SOCIETY OF CARDIOLOGY

\begin{tabular}{|c|c|c|c|c|c|c|}
\hline \multicolumn{2}{|c|}{ Honorary President } & & $\cdots$ & $\cdots$ & & Prof. Charles Laubry (Paris) \\
\hline President .. & . & .. & .. & . & . & Prof. Gustav NyLIN (Stockholm) \\
\hline Vice-Presidents & $\cdots$ & $\cdots$ & $\cdots$ & $\cdots$ & . & $\begin{array}{l}\text { Dr. EVAN BEDFORD (London) } \\
\text { Dr. J. LENÈGRE (Paris) }\end{array}$ \\
\hline $\begin{array}{l}\text { Secretary .. } \\
\text { Treasurer }\end{array}$ & - & $\cdots$ & . & $\cdots$ & - & Dr. Fr. VAN Dooren (Brussels) \\
\hline
\end{tabular}

OPENING OF CONGRESS

September 10, 1952

Sir John Parkinson, Chairman of the Congress and President of the British Cardiac Society, welcomed Members of the Congress.

Professor Charles Laubry, Honorary President of the European Society of Cardiology, addressed the assembly.

Professor Gustav Nylin, President of the European Society of Cardiology, gave an address and declared the Congress open. 
Programme of Scientific Sessions

Wednesday, September 10. Morning: Beveridge Hall

Coronary Artery Disease

Joseph Lambert (Spa, Belgium). Value of additional unipolar leads for the diagnosis of localization and extension of myocardial infarctions.

William Evans (London). The electrocardiogram in 1000 patients with cardiac infarction.

Irving S. Wright (New York). An evaluation of the anticoagulants.

P. J. D. Snow, A. Morgan Jones, and K. Daber (Manchester). A study of coronary and myocardial lesions.

E. Coelho, J. M. Fonseca, C. Rocha Pinto, and A. Nunes (Lisbon). Coronary arteriography in the living subject and its importance for the study of anastomoses of the coronary arteries.

Wednesday, September 10. Morning: Assembly Hall

Congenital Heart Disease

J. F. Goodwin and A. Pagnoni (London). Cardiographic diagnosis of combined ventricular hypertrophy.

J. Laham, C. Metianu, M. Durand, and G. Dauzier (Paris). Electrocardiographic study of combined ventricular hypertrophy in congenital heart disease.

J. Dankmeijer and J. Los (Leiden). Embryology of the pulmonary veins.

J. Lequime, F. Courtoy, H. Denolin, and J. Kenis (Brussels). Hæmodynamics in isolated ventricular septal defect.

Ruby M. Collister, J. Dankmeijer, and H. A. Snellen (Leiden). Vascular changes in the collateral lung-circulation in severe pulmonary stenosis and atresia.

C. Metianu, M. Durand, and T. Doliopoulos (Paris). The significance of a negative $P$ wave in lead $I$ in congenital heart disease.

Maurice Campbell and Geoffrey Reynolds (London). The significance of the direction of PI in dextrocardia and isolated lævocardia.

\section{Wednesday, September 10. Afternoon: Beveridge Hall}

Congenttal Heart Disease

J. Lind and C. Wegelius (Stockholm). Changes in the human circulation at birth. An angiocardiographic study.

H. Lichtenstein, J. Lind, and C. Wegelius (Stockholm). Angiocardiography in experimental heart disease.

E. Donzelot, R. Heim de Balsac, C. Metianu, M. Durand, and R. Guillemot (Paris). Radiological study of 400 cases and anotomical and radiological comparison of 60 necropsies of tetralogy of Fallot.

C. Metianu, M. Durand, J. Laham, and G. Dauzier (Paris). Electrocardiographic study of 32 cases of pulmonary stenosis with intact ventricular septum.

G. Jonsson, B. Broden, and J. Karnell (Stockholm). Selective visualization of pulmonary stenosis.

A. G. Brom (Holland). The value of valvotomy in pure pulmonary stenosis and in pulmonary stenosis combined with over-riding aorta.

J. Karnell (Stockholm). Surgical treatment of coarctation of the aorta.

F. d'Allaines, N. du Bouchet, and B. I. Latscha (Paris). Hexamethonium during operations for stenosis of the aortic isthmus.

C. C. Maggi and F. Seitun (Milan). Clinical, radiological, and tomographical study of the rare forms of stenosis of the thoracic aorta. 
Wednesday, September 10. Afternoon: Assembly Hall

ELECTROCARDIOGRAPHY

Jean Lenègre and Henri Chevalier (Paris). Correlation of electrocardiograms with lesions of the Tawara-His system of A-V block and bundle branch block, and ventricular hypertrophy.

Fr. Van Dooren and N. Boyadjian (Brussels). Configuration of the QRS complexes in A-V block.

L. Cabral (Lisbon). S-waves in intraventricular block.

R. Hegglin, H. Grauer, and A. Munchinger (Zurich). Experimental investigations on the cause of Q-T prolongation.

V. Brossa Torres (Barcelona). The clinical value of monopolar leads.

P. Rijlant (Brussels). Polygraphic exploration of the distribution of cardiac potentials on the surface of the thorax.

S. Caccuri and G. Grazziani (Naples). The ventricular gradient in bundle branch block.

J. Varela de Seijas Aguilar, E. Uriel Morales, and H. Herrero Botas (San Rafael). The ventricular gradient with reference to the repolarization process.

M. Corti and V. Macchi (Milan). Electrocardiograms known as " of overload" following changes in the intracavitary pressures after surgical treatment.

Thursday, September 11. Morning: Beveridge Hall

Symposium on the Surgical Treatment of Mitral Stenosis

Opening Speakers

Maurice Campbell (London). P. Soulié (Paris). L. Werkö (Stockholm). R. Froment (Lyons). Paul Wood (London).

Followed by

T. Holmes Sellors (London). P. Santy (Lyons). C. Crafoord (Stockholm). A. M. Dogliotti (Turin). H. A. Snellen (Holland). G. A. Mason and W. G. A. Swan (Newcastle). O. Branko (Yugoslavia). Erik Warburg (Copenhagen).

Thursday, September 11. Afternoon: MacMillan Hall

Further Papers on the Surgical Treatment of Mitral Stenosis

W. Bolt and H. Venrath (Germany). Functional analysis with special reference to surgical treatment of mitral stenosis.

V. Puddu, L. Comberiati, A. Collicelli, and A. Sensi (Rome). Electrocardiographic, phonocardiographic, and electrokymographic changes in mitral stenosis after commissurotomy.

A. Cordeiro and E. Lima Basto (Lisbon). Post-operative course of mitral valvotomy.

F. S. P. van Buchem, J. Nieveen, B. P. A. A. Homan, and W. E. Marring (Holland). Some observations on patients operated on for mitral stenosis.

L. Condorelli (Rome). The regulator mechanisms of pulmonary arterial pressure.

M. Servelle (Paris). Experimental study of mitral valvoplasty: hæmodynamics and results.

F. Jackson (Newcastle). Pulmonary artery and pulmonary capillary pressures in mitral stenosis, and their response to exercise.

H. A. Snellen, J. Dankmeijer, P. H. M. Schilling, J. Van Dam, H. G. Verdonk (Holland). Clinical significance of biopsies from the left lung and left auricle in mitral stenosis. 
G. Nylin and G. Hevesey (Stockholm). Application of Thorium B. labelled red corpuscles in the determination of the blood volume.

G. W. Pickering, M. Hamilton, and G. S. C. Sowry (London). The inheritance of benign essential hypertension.

H. Welti and C. Lian (Paris). The treatment of essential hypertension by an arterio-venous fistula.

F. Lenzi and A. Caniggia (Siena). Experiments on the osmodynamic energy accumulator theory.

R. Daley and I. McMillan (London). The heart beat in the dog as shown by high speed cinematography.

J. Lequime, P. Courtoy, and J. Kenis (Brussels). Hæmodynamics in combined left and right ventricular failure.

A. Poppi, G. Labo, and G. Lenzi (Bologna). Liver and pancreas function in heart disease.

L. Gallavardin, R. Froment, and P. Cahen (Lyon). Benign forms of paroxysmal ventricular tachycardia.

Thursday, September 11. Afternoon: Assembly Hall

MAINLY ELECTROCARDIOGRAPHY AND VeCTORCARDIOGRAPHY

A. de Sousa Pereira (Oporto). Superior cervical sympathectomy and ligation of external carotid artery in the treatment of cerebral vascular diseases.

M. Iverson (Copenhagen). Heart disease and prostatic surgery.

G. Agostoni (Milan). The zone of the aortic isthmus " locus minoris resistentiæ " in cases of violent trauma of the chest.

V. Slavkovic (Yugoslavia). Clinical significance of aVR leads in which the main QRS deflection is upward.

J. Gibert-Queraltö, M. Torner-Soler, J. Paravisini, and J. M. Morato-Portell (Barcelona). The physiogenesis of the left intracavitary electrocardiogram.

P. Meyer, R. Herr, Cl. Schmidt, P. Millian (Strasbourg). Unipolar dorsal leads, especially V8 and Inf. 8 in electrocardiography.

M. Segers (Brussels). Preponderance considered as an intraventricular block.

M. Regnier and B. Taccardi (Belgium). The frontal vectorcardiogram in man.

R. Wenger (Vienna). The vectorcardiographic investigations in incomplete bundle branch block.

R. Ivancic (Zagreb). Transthoracic bipolar leads.

J. Shillingford and W. Brigden (London). The vectorcardiogram in mitral stenosis.

Friday, September 12. Morning: Beveridge Hall

Mitral Stenosis and Mitral Incompetence

G. Biörck, O. Axen, H. Krook, L. Andren, and H. B. Wulff (Stockholm). The relative merits of various diagnostic methods in mitral valvular disease.

H. E. Holling and A. Venner (London). The diagnosis of mitral incompetence.

W. Brigden and A. Leatham (London). Mitral incompetence.

S. R. Kjellberg, U. Rudhe, H. Eliasch, and L. Werkö (Stockholm). Evidence for left auricular contraction and mitral regurgitation in mitral valvular disease.

R. Turner (Edinburgh). The surgical treatment of mitral incompetence. 
P. F. Angelino and A. Actis-Dato (Milan and Turin). Angiocardiopneumography in mitral stenosis.

J. Facquet, J. M. Lemoine, P. Alhomme, and G. Lefebvre (Carnot). The measurement of the left auricular pressure through the bronchus.

I. Mahaim, P. Desbaillets, and J. Wyss (Lausanne). The mitral stenosing left auricular polyp and commissurotomy: a new symptom.

Friday, September 12. Morning: Assembly Hall

Ballistocardiography, Electrokymography, and Miscellaneous Subjects

H. Burger (Utrecht). The physical principles of ballistocardiography.

L. Jonnart and J. Lequime (Brussels). Ballistocardiography from the physical standpoint.

R. Boehmig (Karlsruhe). Morphological development of the different types of endocarditis.

E. Donzelot and J. E. Escalle (Paris). Bacteriology and treatment of subacute bacterial endocarditis (Osler's disease).

R. Scalabrino (Milan). Subacute bacterial endocarditis with positive and negative blood culture, and its treatment.

A. Gonin, R. Froment, and J. Gravier (Lyons). Tuberculous pericarditis progressing to constrictive pericarditis.

F. Estape (Barcelona). Mitral destruction without valvular disease in constrictive pericarditis.

J. Paravisini-Parra, J. Gibert-Queraltö, M. Torner-Soler, J. Moralto-Portell, and A. GregorichSerrat (Barcelona). The investigation of constrictive pericarditis before surgical treatment.

L. Trias de Bes and F. Ballesta Barcons (Barcelona). The tolerance to khellin.

Friday, September 12. Afternoon: Beveridge Hall

Miscellaneous Subjects

A. Juvenelle, J. Lind, and C. Wegelius (Stockholm). Experimental hypothermia and cardiac surgery. Observations with an extra-corporeal circulation at reduced body temperature.

K. Blumberger (Dusseldorf). The dynamics of mitral and aortic valve diseases.

G. Minot, C. Lian, Herbert, and Rager (Paris). Simultaneous registration of the electrical and mechanical phenomena of the heart and vessels.

A. Thomas (Cardiff). The vascular lesion of pneumoconiosis.

Evans Jones and I. McMillan (London). The movement of aortic and pulmonary valves studied post-mortem by colour cinematography.

V. Debenedetti (Ivrea, Italy). The lasting inversion or flattening of the $\mathrm{T}$ wave in pulmonary embolism.

K. E. Grewin (Stockholm). The normal electrocardiogram in pregnant women during the last trimester and after delivery.

M. Holzmann (Zurich). Influence of respiration upon arrhythmias.

J. Ulrich (Germany). Contribution to the physiology of the heart.

Friday, September 12. Afternoon: Assembly Hall

Coronary Disease and Peripheral Vascular Disease

H. Malmros (Sweden). The relationship of diseases of the coronary arteries and of the gall bladder.

V. Lapiccirella and G. Weber (Florence). The localization of coronary and gastro-mesenteric arteriosclerosis with reference to associated gastro-mesenteric syndromes.

K. Shirley Smith and C. Papp (London). Electrocardiographic assessment of posterior cardiac infarction. 
G. Michaelides, H. Tsevreni, and D. Avgoustakis (Athens). Observations on the treatment of cardiac infarction by means of anticoagulants.

E. Donzelot and H. Kaufman (Paris). Angina and heparin.

Y. Bouvrain, R. Tricot, P. Vernant, and P. Meudic (France). A study of the freezing point of serum and of azotemia in recent cardiac infarction.

P. Hedlund (Stockholm). The appearance of acute phase protein in myocardial infarction.

B. Ejrup (Stockholm). Fluorescin circulation rate in peripheral vascular diseases.

G. Bendiera (Genoa). The determination of functional damage in the estimate of the gravity and evolution of vessel diseases of lower limbs.

The Organizing Committee expresses its gratitude to the following firms which have generously contributed towards the expenses of the Congress:

Atlas Werke.

Benger Laboratories Ltd.

Boots Pure Drug Co.

Burroughs Wellcome \& Co.

Cambridge Instrument Co. Ltd.

Carreras Ltd.

A. C. Cossor Ltd.

General Radiological Ltd.

The Genito Urinary Manufacturing Co. Ltd.

Imperial Chemical Industries Ltd.

Kodak Ltd.

Laboratory Nativelle Ltd.

Lloyd Luke (Medical Books) Ltd.
New Electronic Products Ltd.

Officine Galileo.

Oxygenaire Ltd.

George Petit.

Pharmaceutical Laboratories Geigy Ltd.

Philips Electrical Ltd.

Portable X-Rays.

Riker Laboratories Ltd.

Shandon Scientific Co. Ltd.

Sierex Ltd.

E. R. Squibb \& Sons Ltd.

John Wyeth \& Brother Ltd. 